\title{
BobCats, infestation, and a new library
}

\author{
By Jon Eldredge \\ Albuquerque, New Mexico
}

\section{Three academic libraries were winners in this year's John Cotton Dana Library Public Relations Award contest.}

W hat do a BobCat, silverfish and a new library have in common? Not much unless you are describing themes of the public relations projects which recently received recognition in the 1984 John Cotton Dana Library Public Relations Award contest. This year three academic libraries won awards in the contest. According to the contest judges these three winning entries represented nearly ideal models of how a library public relations program should be planned and evaluated.

The University of Texas Health Science Center at San Antonio Library won a John Cotton Dana Award for its year-long, comprehensive public relations program designed to introduce users to a new library building. The Bobst Library at New York University received a Special Award in the contest for its promotion of the library mascot "BobCat," named after the acronym for a new online card catalog. The Mann Library at Cornell University also received a Special Award for its innovative campaign to educate users about the problems caused by insect and rodent infestation due to the presence of food and drink in the library.

Ten academic libraries submitted entries to this year's contest. Four of the entries requested to be considered for the John Cotton Dana Award, which recognizes a library's overall, year-long public relations program. The remaining entries sought consideration for a Special Award, which acknowledges the success of a single component of an overall library public relations program. This year's entrants included four large university research libraries, two graduate school libraries, two four-year college or university libraries, and two community college libraries. Surprisingly, only three entries came from libraries serving what might be considered small academic communities. In the past, such libraries have fared well in the contest. All regions of the United States were generally represented among the entrants with the exception of the southeastern and north central states. No academic libraries located outside of the United States entered the contest this year.

The library public relations activities of the winning entries to this year's contest distinguished themselves from other entries in a number of significant ways. Most important, the winning entries demonstrated evidence of thorough public relations planning from the initial stage of formulating clearly-articulated, realistic goals through to the final stage of accurately evaluating the degree of success observed in the execution of these planned public relations activities. The strongest contenders actually attempted to prove through quantitative methods that their public relations programs had attained a measurable level of success. The winners directly related the missions of their libraries to the goals of their public relations programs. These goals were, in turn, closely tied to the objectives of specific public relations activities.

The scrapbook and audio-visual program entries submitted for judging by the award winners lucidly described the public relations activities at these libraries. In this regard, carefully and concisely written scrapbooks which contained only a sample of project materials had a definite advan- 


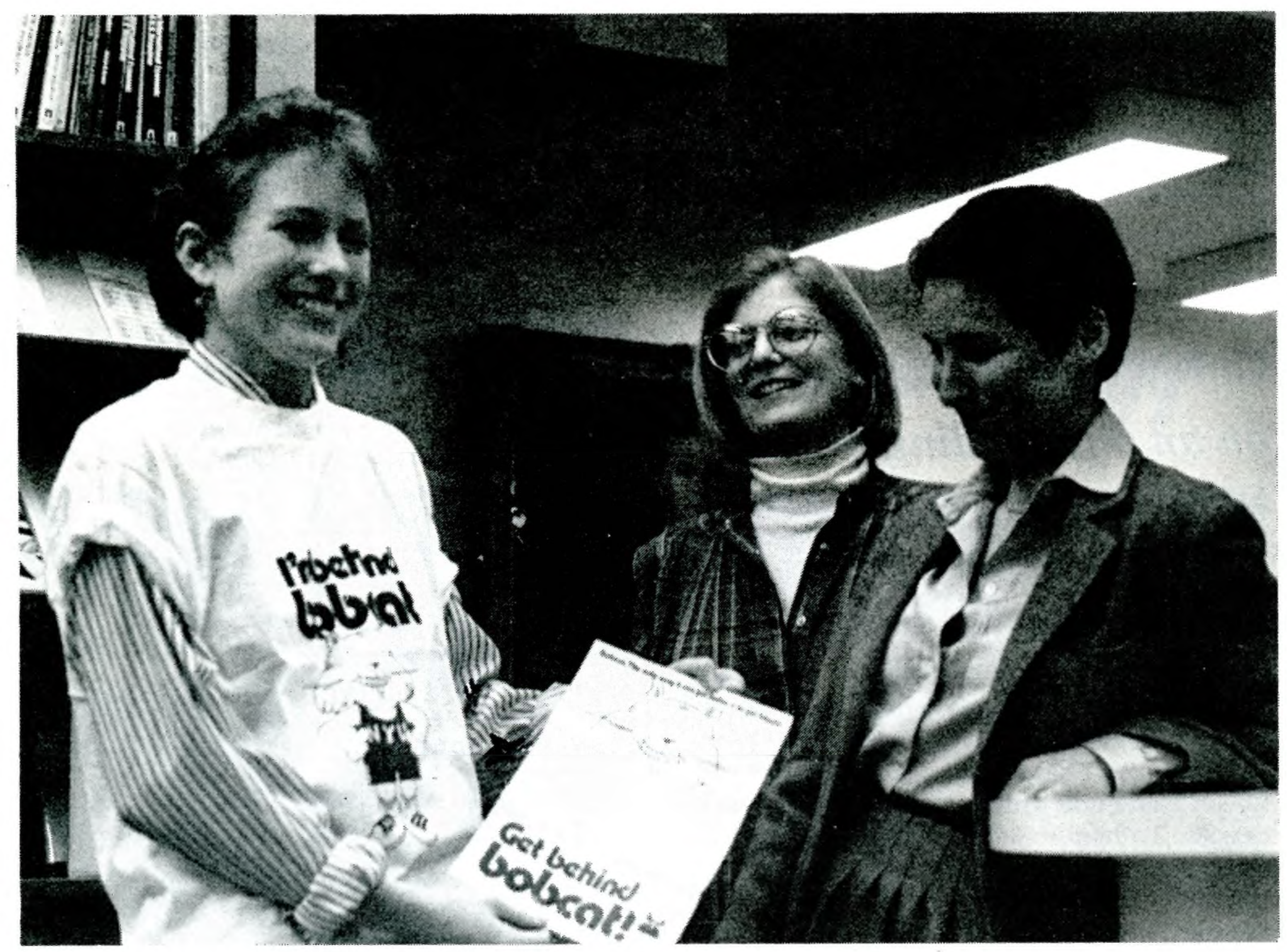

Anne Hagedorn and friends show off the NYU Bobcat T-shirt and brochure.

tage in the contest over bulky and wordy scrapbook entries. Libraries that creatively utilized available resources in their public relations activities generally were more likely to win an award, regardless of the actual amounts of financial resources at their disposal. The Mann Library at Cornell University illustrates this point by its expenditure of less than $\$ 200$ on what was judged to be an outstanding public relations project.

New York University's Bobst Library won a Special Award for its unusual and creative use of a mascot named BobCat. The mascot was designed to convey the philosophy behind the newlyinstituted user-friendly online Bobst Catalog. In addition, the BobCat symbolized the changing mission of the library from being a "warehouse" of research materials to one of providing a dynamic array of user services for a diverse and geographically dispersed academic community located in a large urban area. The grinning, lovable BobCat mascot was adaptable to many media including brochures, T-shirts, stationery, and posters. The university varsity basketball team even adopted the library's BobCat as its own mascot.

The contest judges praised the Bobst Library for its explicitly stated and quantified objectives connected with the BobCat promotional project. Moreover, the evaluation phase of the project was conducted with methods that were both comprehensive and appropriate for the type of activities involved. The judges were especially intrigued by the successful application of a public relations device like the BobCat mascot to an academic library environment. Normally, these types of techniques are associated with the promotion of youth services in school and public libraries. The successful use of the BobCat may possibly signal the beginning of a new era in academic library public relations. The judges also gave the BobCat project hign marks for its cost-effectiveness and for the precision ith which library staff members targeted the project toward specific campus community groups.

The Albert Mann Library at Cornell University received a Special Award for its particularly innovative campaign to keep food and drink out of the building. Rather than assume a negative stance toward users who brought refreshments with them into the building, the library staff decided to educate users about the potential damage to research materials caused by insects or rodents attracted to leftovers. Because the Mann Library serves academic programs in the fields of agriculture, life sciences and human ecology, this public relations campaign was designed to appeal to these specific user audiences. This low-cost but dramatic campaign epitomized the professional ideal of "preventive public relations."

Users were educated about the types of damage to library materials caused by insects and rodents through several activities. First, a somewhat 
tongue-in-cheek scientific study conducted by the staff on the varieties of trash found in the library was displayed in a very striking exhibit at the entrance to the library. Second, the library sponsored a logo contest for its campaign among the student user population. The winning logo featured a caricature of an insect reading and eating in the library (see cover). Third, the logo and other drawings of

\section{Cornell spent less than $\$ 200$}

\section{on an outstanding public}

\section{relations project.}

library pests were printed on different bookmarks distributed at the circulation desk. In general, the project assumed a positive tone to avoid the typically negative image often associated with efforts to curb food and drink problems in academic libraries. To help maintain a positive tone to this campaign, humorous or playful elements were occasionally interjected into the various public relations activities.

The Mann Library's unique approach to solving a perennial academic library problem earned it high scores in the contest judging process. The judges were impressed by the manner in which the Mann Library clearly defined its goals and objectives so they could be evaluated in a way that could be easily measured. Among the other winning features of the Mann Library's entry was the wise utilization of on-campus resources by the library staff to promote their educational campaign.

The University of Texas Health Science Center at San Antonio Library won a John Cotton Dana Award for an extensive, year-long public relations program intended to introduce users to a new library building. The program, entitled "New Library, New Technology," also sought to heighten awareness about the range of new services available at the recently completed library facility. The centerpiece of the program was a series of attractive library publications that utilized a graphic design to symbolize the arrival of a new age in library services.

In its entry scrapbook, the UTHSCSA Library presented overwhelming evidence of the exhaustive planning and carefully organized execution of its public relations program. Broad goals of the public relations program were linked directly to the major goals of the library. Furthermore, all activities during the year-long program were justified according to specific public relations objectives. The planning activities even included both extensive internal and external library public relations objectives. This entry provided ample evidence to suggest widespread involvement with the program among the library's large staff. The judges were struck by evaluation efforts of the program that attempted to quantify the success of almost all of these public relations activities. It might be noted by librarians at similar kinds of academic libraries that the UTHSCSA Library entered and won a John Cotton Dana Award in the special libraries category of the contest. Because of the relevance of the UTHSCSA Library's award-winning program to all academic libraries it has been reviewed in this article.

There are a number of advantages for academic libraries to enter the John Cotton Dana Library Public Relations Award contest. As has been pointed out in a previous issue (C\&RL News, June 1983, pp. 188-90), during the past decade a respectable percentage of academic libraries that entered the contest actually won an award. For instance, this year three out of ten entries submitted from academic libraries won either a Special Award or a John Cotton Dana Award. An often overlooked fringe benefit of entering the contest is having one's public relations program or projects evaluated by a group of fellow professionals dedicated to the advancement of library promotion. Following the announcement of contest award recipients each year, all entrants are encouraged to contact the committee chairperson to obtain a free, detailed assessment of the strengths and weaknesses of their libraries' public relations activities. In effect, this service represents a free consulting program for all participants in the contest.

This year three professionals from academic institutions served as judges for the contest. During the past few years at least one academic librarian has served as a judge for the contest. These judges understand the special types of problems faced by academic libraries. Thus, they are able to evaluate realistically entries from academic libraries within the proper context. Moreover, the existence of the contest and the possibility of gaining recognition for one's efforts by itself should give librarians an additional incentive to strive for excellence in developing public relations activities. Finally, the reader should be aware that in recent years the contest scheduling procedures have been restructured to encourage greater participation by academic libraries.

Academic librarians contemplating the submission of entries to the contest may wish to consider several suggestions. Even prior to initiating a public relations project, librarians should have a clear idea in the planning stages about what exactly they want to accomplish with their project activities. They should be equally clear about why they think these activities are important regarding the mission of the library. Librarians also should seek to document thoroughly and precisely evidence of the extent of the success of their activities during the evaluation phase of the projects. 


\begin{tabular}{|l|l|l|l|l|l|l|l|l|l|l|l|l|l|l|l|l|l|l|l|}
\hline & & & & & & & & \\
\hline & & & & \\
\hline
\end{tabular}

\section{New Library, New Technology}

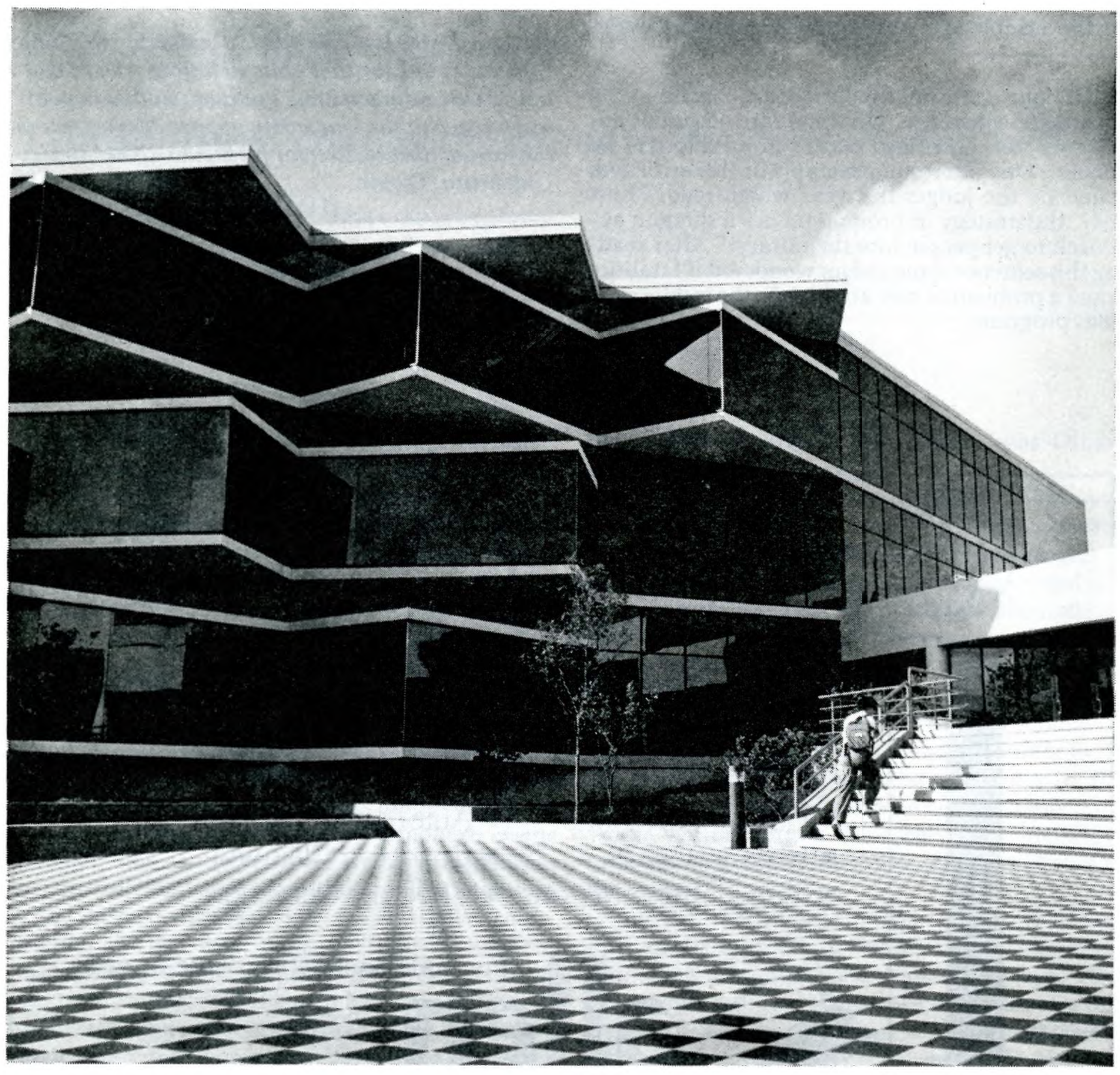

\section{Sponsored by the UTHSCSA Library}

The new University of Texas Health Science Center at San Antonio's new library, and graphics from their promotional efforts. 
Entrants should remember that the panel of ten judges for the contest evaluates about 150 entries over the course of only five working days. Therefore, all entries should concisely capture the essential features of a library's public relations activities. ${ }^{1}$ The importance of brevity in the entries would be difficult to overemphasize. Participants in the contest are advised to design their entries so they can be completely read and reviewed by an individual judge in ten to fifteen minutes' time. Potential entrants most certainly should make an effort to review personally the scrapbooks and audio-visual programs of winning entries to learn what types of qualities characterize a John Cotton Dana Library Public Relations Award winner. These winning entries may be personally examined in the exhibit area during ALA Annual Confer-

${ }^{1}$ Of course, entries should not be concise at the expense of coherence. On some rare occasions applicants have sacrificed clarity in an effort to be concise. One interesting example of this error was found by the judges this year which read: "Last year, the strategy of promotion was a shotgun approach to get people into the library." After reading this sentence some judges wondered if fatalities posed a problem of user attrition in the public relations program. ences or may be obtained via interlibrary loan from the ALA Headquarters Library.

Librarians interested in learning more about the contest should contact the Marketing Division, $\mathrm{H}$. W. Wilson Company, 950 University Avenue, Bronx, NY 10452. The H. W. Wilson Company will be able to provide application forms and information brochures as well. The reader also may wish to consult the past few years of the library literature $^{2}$ for additional suggestions on how to submit a winning entry to the contest. In the fall of 1984 the Library Administration and Management Association will publish a book edited by Ann $\mathrm{H}$. Eastman entitled Great Library Promotion Ideas 1984 in which all award-winning entries from this year's contest will be described.

Editor's Note: Jon Eldredge, a judge for the John Cotton Dana Library Public Relations Award contest, is currently pursuing graduate studies in political science at the University of New Mexico. He is the former library director for Eastern New Mexico University, Clovis.

${ }^{2}$ Some useful advice on increasing one's chances of winning an award can be found in Kathleen Kelly Rummel \& Esther Perica, Persuasive Public Relations For Libraries (ALA, 1983).

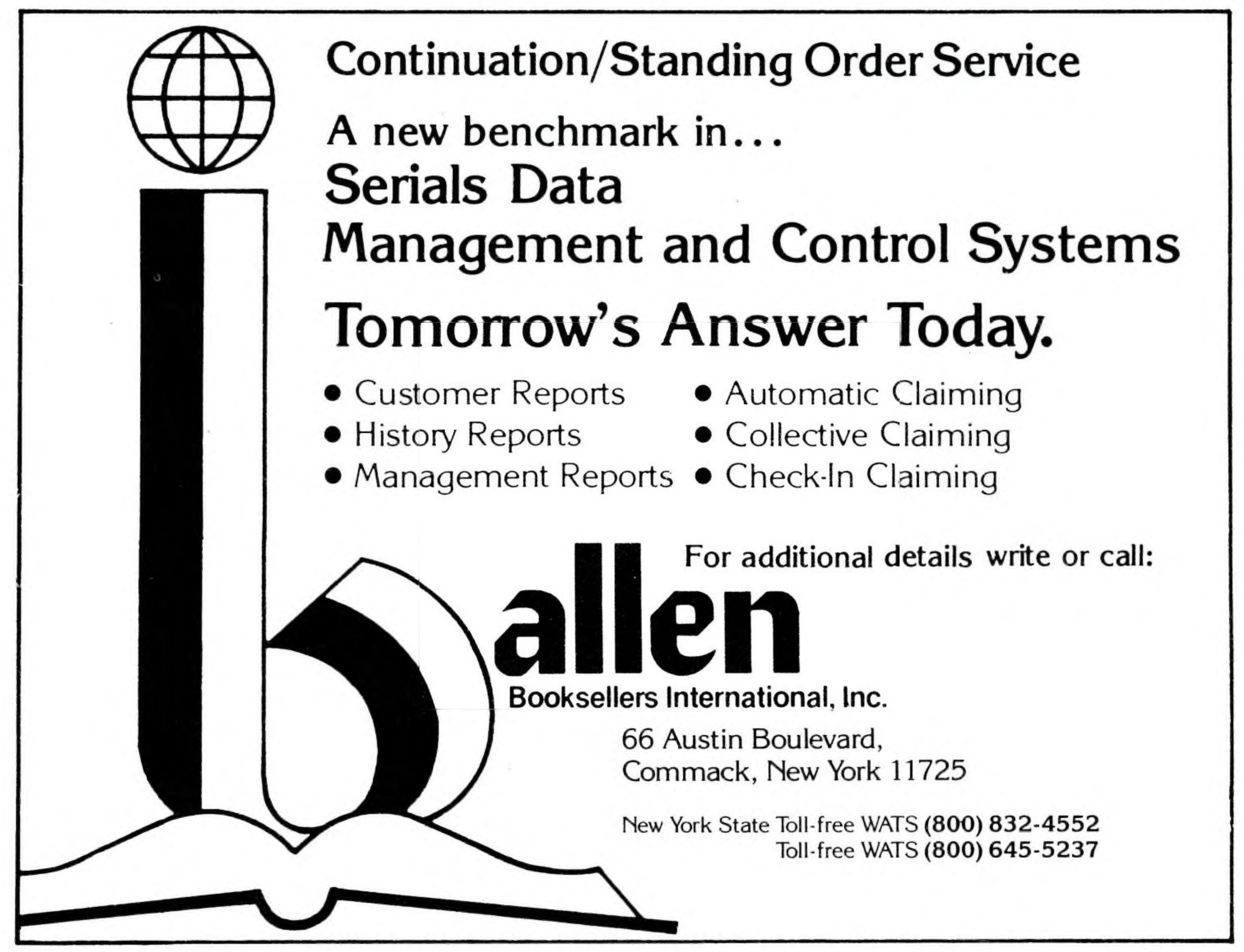

